\title{
Az elektronikus cigarettáról meglévő ismeretek összefoglalása
}

\author{
Cselkó Zsuzsa dr. ${ }^{1}$ - Pénzes Melinda dr. ${ }^{2}$ \\ 'Országos Korányi Tbc és Pulmonológiai Intézet, Budapest \\ ${ }^{2}$ Semmelweis Egyetem, Általános Orvostudományi Kar, Népegészségtani Intézet, Budapest
}

\begin{abstract}
A dohányzást korlátozó szigorítások hatására csökkenő dohányzási arány vezette a gyártókat egy új nikotinélvezeti forma, az elektronikus cigaretta (e-cigaretta) világszintű elterjesztésére. Jelen áttekintés a PubMed adatbázisban lévő publikációk, valamint hazai és nemzetközi tudományos intézetek honlapján közölt összefoglalók és felmérések anyagán alapul. Az e-cigaretta összetételéről és egészségkárosító hatásáról meglévő ismeretek alapján kijelenthető, hogy nem ártalmatlan termék, egyaránt károsan hat a használója és a párát passzívan belélegzők egészségére. Kellően alátámasztott tudományos bizonyítékok továbbra sem igazolják az e-cigaretta előnyeit a leszokás támogatásában, ugyanakkor bizonyított, hogy fenntartja a nikotinfüggőséget, és különösen fiatalok esetében növelheti a rászokás kockázatát. A dohányzás visszaszorítása és a leszokás támogatása céljából hozott intézkedések hatékonyságának szavatolása érdekében kívánatos, hogy az e-cigarettára ugyanazok a szabályok vonatkozzanak, mint a hagyományos dohánytermékekre. Orv. Hetil., 2016, 157(25), 979-986.
\end{abstract}

Kulcsszavak: elektronikus cigaretta, hozzászokás, leszokás

\section{Summary of the existing knowledge about electronic cigarettes}

The decreasing proportion of smokers due to smoking restrictions have led producers to invent and disseminate electronic cigarettes (e-cigarettes) worldwide as a new form of nicotine enjoyment. This review summarizes the existing knowledge about e-cigarettes based on publications of PubMed, and on reviews and research data published by national and international scientific institutions. Present knowledge about the composition of e-cigarettes confirms that they are harmful products since their vapor is equally detrimental to the health of users and bystanders. Their benefits in smoking cessation still have not been justified by adequate scientific evidence, however, it has been proven that e-cigarettes uphold nicotine addiction and may increase the risk of starting conventional cigarette use by youth. In order to ensure the results of tobacco control policy and to assist smoking cessation, the same regulations are to be applied to e-cigarettes as to conventional tobacco products.

Keywords: electronic cigarettes, addiction, smoking cessation

Cselkó, Zs., Pénzes, M. [Summary of the existing knowledge about electronic cigarettes]. Orv. Hetil., 2016, 157(25), 979-986.

(Beérkezett: 2016. március 10.; elfogadva: 2016. április 14.)

\section{Rövidítések}

ENDS = electronic nicotine delivery system; PAH = policiklusos aromás szénhidrogének; TSNA = dohányspecifikus nitrózaminok; VOC = illékony szerves vegyületek; WHO = Egészségügyi Világszervezet

A dohányzás egészségkárosító hatásainak felismerése és a fejlett országoknak a dohányzás visszaszorítására irányuló küzdelme több évtizedes múltra tekint vissza. A do- hányzást korlátozó szigorítások következtében ÉszakAmerikában, Ausztráliában és Nyugat-Európában csökkenő dohányzási arány a gyártókat egy új nikotinélvezeti forma, az elektronikus cigaretta (e-cigaretta) világszintű elterjesztésére késztette, amely révén fenntartható a fizikai és lelki függőség, egyszersmind megkerülhetők a füstölést tiltó rendelkezések [1]. Az e-cigaretta jelenleg tapasztalható térhódítása hasonlít a hagyományos cigaretta (szárított, finomra vágott dohánylevelek papírba csomagolva) egy évszázaddal ezelőtti előretöré- 
séhez, amikor az átvette a szivar, a pipa és a bagó helyét, illetve amikor mintegy 40 évvel ezelőtt a társadalmat megtévesztő, alacsony kátránytartalmú cigaretta népszerüsítése átformálta a dohánypiacot [2]. Éppen ezért aggodalomra ad okot, hogy a hagyományos cigarettához hasonlóan, az e-cigaretta még az előtt terjedt el, hogy megnyugtató válaszok születtek volna a termék biztonságát, a leszokáshoz nyújtott hatékonyságát és legfőképpen a lakosság egészségére gyakorolt hatását illetően [3]. További riasztó tényező, hogy ez a technológiai újdonság a sokféle, kedvelt ízesítésű utántöltő folyadék, valamint a dohányipar reklámtevékenysége hatására vonzóvá válhat és ösztönözheti a termék kipróbálását különösen a fiatal, magasabb jövedelmú, városi lakosság körében [4].

\section{Módszer}

Tanulmányunk a PubMed adatbázisban lévő publikációkon, valamint hazai és nemzetközi tudományos intézetek honlapján közölt összefoglalókon és felméréseken alapul. Az adatbázisban a következő keresőszavakat és kombinációkat használtuk: „elektronikus cigaretta” („electronic cigarette”), „elektronikus cigaretta toxicitása” („electronic cigarette toxicity”), „elektronikus cigaretta káros hatások” („electronic cigarette adverse effects”), „elektronikus cigaretta használat” (electronic cigarette use”), illetve „elektronikus cigaretta dohányzás leszokás” („electronic cigarette smoking cessation”). A keresés során egy korábbi közlemény irodalomkutatásának (2013. július-2015. december közötti időszak) lezárási időpontjától tekintettük át a publikációkat [5]. Követelmény volt, hogy a publikáció magyar vagy angol nyelvü legyen, illetve a más nyelven készült anyag rendelkezzen angol nyelvű összefoglalóval. Elemzésünkben három, a klinikusok érdeklődését leginkább érintő kérdéskört vizsgáltunk: 1. az e-cigaretta összetevőinek egészségkárosító hatásai, 2 . az e-cigaretta-használat gyakorisága és szerepe a rászokásban, illetve 3 . az e-cigaretta szerepe a leszokás támogatásában. Nem dolgoztuk fel azokat a közleményeket, amelyek témája nem kapcsolódott szorosan a témához, vagy szerkesztői, illetve véleménycikkek voltak.

\section{Az e-cigaretta felépítése és jellemzői}

$\mathrm{Az}$ elektronikus nikotinbeviteli rendszerek (electronic nicotine delivery system - ENDS) kategóriájába tartozó eszközök közül az e-cigaretta terjedt el leginkább. Müködése a készülék tartályában lévő folyadék fütőszállal történő felmelegítésén és aeroszollá porlasztásán alapszik. Az e-cigaretta-patronokban lévő folyadék (e-liquid) legfontosabb összetevői a nikotin, az oldószer (a folyadék alapja), a víz, valamint a különböző adalékanyagok és ízesítő aromák [3]. Az e-cigaretta használatának célja a dohányzás imitálása, ezért a felhasználók körében a nikotintartalmú folyadék a leginkább elterjedt [3].
Az utántöltő folyadékok többségében (99\%) lévő nikotinnak, a függőség kialakulásában betöltött szerepe mellett, ma már számos más egészségkárosító hatása ismert. Kiemelendő a nikotinnak és származékainak az érelmeszesedés, az inzulinrezisztencia, illetve a daganatos betegségek kialakulásában és progressziójában betöltött szerepe [6]. Ismert a nikotin káros hatása a termékenységre és a magzati fejlődésre, továbbá az is, hogy a magzatként vagy gyermekkorban elszenvedett nikotinexpozíció hozzájárulhat a fiatalkori viselkedészavarok kialakulásához [6]. A nikotin emberi szervezetre gyakorolt hatásait mutatja be a korábbi összefoglaló közleményünk alapján [5] elkészített 1 . táblázat. A nikotin azonnali hatást gyakorol a szív- és érrendszerre az e-cigaretta használata során is: miután a véráramba került, 5 percen belül már tapasztalható, hogy a kiserek összehúzódnak, jelentősen megemelkedik a szívfrekvencia és a vérnyomás az alapállapothoz képest, és a készülék használatakor ezen a magasabb értéken állandósul. Kutatások alátámasztják, hogy szívinfarktus utáni nikotinexpozíció kedvezőtlenül befolyásolja a felépülést [7]. A felszívódó nikotin mennyisége a készüléktől és a felhasználótól függően változhat [8], ugyanakkor gyakorlott e-cigarettázó esetében a plazma nikotinszintje, illetve - metabolitja - a kotininszint megfelel a hagyományos cigarettát fogyasztóknál tapasztalt értékeknek, továbbá, különösen a magas nikotinkoncentrációjú folyadékok esetében, a vér nikotinkoncentrációjának emelkedési dinamikája hasonló a hagyományos cigaretta szívásakor tapasztaltakhoz $[3,9,10]$. Mivel az e-cigaretta által generált aeroszol passzív belélegzése nyomán ugyanolyan mértékben emelkedik a plazmanikotinszint, mint a hagyományos cigaretta füstjének passzív elszenvedése során, az e-cigaretta használata nem védi ki a másodlagos dohányzás okozta nikotinterhelést [3].

Az e-cigaretta és az utántöltő folyadékok gyakran szabályokat nélkülöző gyártása folytán a közelmúltban világszerte megnövekedett a nikotin okozta mérgezések száma: az Egyesült Államokban bejelentett esetek több mint fele öt év alatti gyermekeknél fordult elő [11-13]. A patronokon feltüntetett nikotinkoncentráció sok esetben jelentősen - több mint a hibahatárnak számító 10\%-kal - eltér a folyadékban mérttől [7]. A bőrön keresztül felszívódó, illetve a véletlenül vagy öngyilkossági szándékkal lenyelt nikotin okozta mérgezések néhány esetben halállal jártak [12, 13]. A tudomány által jelenleg széleskörúen elfogadott korábbi vizsgálatok becslése alapján felnőtteknek 40-60 mg, gyermekeknek már 6 mg nikotin véletlen lenyelése életveszélyes lehet [14]. Más vizsgálatok ennek az értéknek mintegy tízszeresét állapítják meg, habár a mérgezésre utaló tünetek már alacsonyabb értékeknél jelentkeznek [15]. Mindazonáltal aggasztó, hogy a 2014-ben elfogadott európai dohánytermék-irányelv [16] utat enged az egészségre ártalmas mértékű nikotinkoncentrációjú patronok $(20 \mathrm{mg} / \mathrm{ml}$; $2 \mathrm{ml}$-es patronok) és $10 \mathrm{ml}$-es utántöltő folyadékkonténerek forgalmazásának, bár igaz, hogy nagyobb hang- 
Szív- és érrendszerre gyakorolt Stimulálja a szimpatikus idegrendszert, emeli a szívfrekvenciát, a vérnyomást és fokozza a szívizom hatás Összehúzódását. Laboratóriumi körülmények között az intravénásan bejuttatott nikotin, a nikotinos orrspray és a nikotinos rágógumi a dohányzással egyező mértékben, 10-15 ütés/perccel emelte a szívfrekvenciát és 5-10 Hgmm-rel a vérnyomást [1]. Károsítja az endothelsejteket, átalakítja azok struktúráját és intimavastagodást idéz elő. Fokozza a DNS-szintézist, a sejtosztódást és az endothelproliferációt, amelynek kitüntetett szerepe van a tumorangiogenezisben is. Növeli az angiogenezisben szerepet játszó faktorok kiválasztását (NO, prosztaciklin, VEGF és FGF). Nikotin hatására fokozódik a citokinek kiválasztása és a neutrofilek kitapadása az atheroscleroticus laesióhoz [1].

Rákkeltő hatás Az oxidatív stressz okozta genetikai változások elősegítésén keresztül közvetlenül és közvetetten hozzájárul a karcinogenezishez, elsősorban a nem kissejtes tüdőrák esetében [1]. Az angiogenezisben szerepet játszó faktorok (NO, prosztaciklin, VEGF és FGF) szérumkoncentrációjának emelésén keresztül fokozza a tumorszövet vérellátását [1]. A nACh-receptor aktiválásán keresztül támogatja a tumorsejtek elvándorlását, szövetinvázióját és a mesenchymába való betörését [1]. Az apoptózis mérséklése révén csökkenti a kemo- és radioterápia hatékonyságát [1]. A dohányfeldolgozás és a dohányzás során a nikotin egy része úgynevezett dohányspecifikus nitrózaminokká (TSNA) alakul, amelyek közül egyes metabolitok az e-cigaretta-folyadékban és a párában is megtalálhatók [7]. Bár a cigarettafüsthöz képest akár 400-szor kisebb koncentrációban fordulnak elő, de némelyik mértéke elég magas ahhoz, hogy fokozza a tumorképződés kockázatát a légutakban [7]. Elsősorban az NNAL (4-[metilnitrózamino]-1-[3-piridil]-1-butanol), az NNK (4-[metilnitrózamino]-1-[3-piridil]-1-butanon) és az NNN (N'-nitrózonornikotin) felelős a daganatok kialakulásáért és progressziójáért, a sejtek fokozott proliferációján és az apoptózis kiiktatásán keresztül [1]

\begin{tabular}{|c|c|}
\hline Inzulinrezisztencia & $\begin{array}{l}\text { A nikotin emeli az inzulinantagonista hormonok (katecholaminok, kortizol, növekedési hormon) szintjét } \\
\text { a véráramban, fokozza a szimpatikus idegrendszer múködését, amely mechanizmusokon keresztül növeli az } \\
\text { inzulinrezisztenciát [1]. }\end{array}$ \\
\hline Lipidháztartás eltérései & $\begin{array}{l}\text { Nikotin hatására emelkedik a plazma epinefrinszintje, amely fokozott lipolízist eredményez a zsírszövetekben. } \\
\text { A lipolízis hatására felszabaduló szabad zsírsavak a májban trigliceridekké alakulnak, ezért a plazmában } \\
\text { jelentősen felszaporodik a VLDL és az LDL, egyúttal csökken a HDL-koleszterin, amely változások } \\
\text { hozzájárulnak az atherogenesishez. A nikotinbevitel fogyást és dyslipidaemiát is okoz, amely utóbbi magában } \\
\text { hordozza a szív- és érrendszeri komplikációk lehetőségét [1]. }\end{array}$ \\
\hline $\begin{array}{l}\text { Termékenységre és magzatra } \\
\text { gyakorolt káros hatások }\end{array}$ & $\begin{array}{l}\text { A nikotin csökkenti a placenta vérellátását, amely magzati hypoxiához és acidosishoz vezethet. Számos } \\
\text { veleszületett és viselkedési rendellenesség kialakulásához hozzájárulhat: a magzatok tüdejének tömege, } \\
\text { térfogata és funkciója elmarad az egészségestől; hatással van a magzat mozgására, amely fontos szereppel bír } \\
\text { az embriógenezis során; káros hatással van a fül külső szőrsejtjeinek fejlődésére, ezáltal a hallásra és nyelvi } \\
\text { készségekre. Károsíthatja a petevezeték múködését, így növeli a méhen kívüli terhesség, a teherbe esési } \\
\text { nehézségek előfordulásának valószínúségét. Az in utero elszenvedett vagy a serdülókori dohányzásból } \\
\text { következó nikotinbevitel jelentősen megemeli a később jelentkező szorongásos kórképek és a pánikbetegség } \\
\text { megnyilvánulásának kockázatát, ugyanis a nikotin a legintenzívebb fejlődési szakaszában károsítja az } \\
\text { idegsejteket [l]. }\end{array}$ \\
\hline
\end{tabular}

FGF = fibroblastnövekedési faktor; $\mathrm{HDL}=$ magas sűrúségű lipoprotein; $\mathrm{LDL}=$ alacsony sűrűségű lipoprotein; nAch = nikotinos acetil-kolin; $\mathrm{NO}=$ nitrogén-monoxid; VEGF = vascularis endothelialis növekedési faktor; VLDL = nagyon alacsony sứrüségü lipoprotein.

súlyt helyez a készülék biztonságos csomagolására. További aggodalomra ad okot, hogy az e-cigarettát már nem csupán a nikotin, hanem egyéb, függőséget okozó szerek szervezetbe juttatására is használják; a világhálón szabadon hozzáférhetők a heroin, a kokain és a hasis utántöltő folyadékba keveréséhez ajánlott receptek [17].

Az e-cigarettát sokszor ártalmatlan termékként reklámozzák, amely a nikotinon kívül csupán másodperceken belül elillanó vízgőzt bocsát ki a használat során, és sokat hangoztatott érv, hogy kevésbé káros, mint a hagyományos cigaretta $[3,18]$. Az e-cigaretta által elóállított pára kémiai és fizikai tulajdonságait nem csupán a folyadék összetevői befolyásolják, hanem a készülék típusa (hányadik generációs készülék, milyen feszültségen üzemel, a készülék előállításához felhasznált anyagok), a felhasználó személye (e-cigaretta-használatra vonatkozó gyakorlat, szippantások között eltelt idő, életkor, nem, egészségi állapot), valamint a környezet (időjárás, légáramlás, zárt térben a helyiség mérete, e-cigaretta-hasz- nálók száma a közelben) is [7]. Számos összetevó változatlanul kerül a párába, míg mások a magas hőmérséklet hatására lebomlanak, átalakulnak, és mérgező vegyületek jönnek létre [19, 20]. A fentiek figyelembevétele mellett számos más körülmény is nehezíti a viszonylag új kutatási területen szerzett ellentmondásos tapasztalatok értékelhetőségét: a vizsgálatok módszertani hibái, összeférhetetlenségi tényezők (a dohánygyárak szponzorálásával készült tanulmányok adatainak vitatható hitelessége) és a hosszú távú egészségkárosító hatások vizsgálatának hiánya [3]. A meglévő ismeretek alapján azonban egyértelmú, hogy az e-cigaretta nem ártalmatlan termék.

Az oldószerként alkalmazott propilénglikol, illetve glicerin vagy ezek bármilyen arányú keverékének (amelyek a folyadék mintegy 70-80\%-át alkotják és a füstképzéshez szükségesek) belégzése szem-, torok- és légcső-irritációt okozhat $[19,21]$. A hosszú távon vagy rendszeresen belélegzett, nagy mennyiségű propilénglikol káros hatással lehet a központi idegrendszer és a lép múködé- 
sére, valamint magatartás-változást idézhet elő [3]. Egyes közlemények szerint az egy nap alatt belélegzett propilénglikol és glicerin mennyisége megközelíti a foglalkozás-egészségügyi határértéket [3]. Más vizsgálatok a perifériás légutak szúkuuletét írták le propilénglikol okozta irritáció hatására, amely ráirányítja a figyelmet az e-cigaretta használatának veszélyeire asztmás, emphysemás vagy krónikus bronchitisben szenvedő betegek esetében [3]. A készülék páraképzéséhez szükséges magas hőmérséklet kedvez az oldószer lebomlásának, amelynek hatására olyan rákkeltő, nyálkahártya-irritáns és tüdőszövet-károsító karbonilvegyületek (formaldehid, acetaldehid, akrolein és aceton) keletkezhetnek, amelyek a cigarettafüstben is megtalálhatók [19], mi több, akár háromszoros mennyiségben vannak jelen a párában [7]. A különböző karbonilvegyületek egyidejű jelenlétekor összeadódik a légutak epitheliumára gyakorolt rákkeltő és mérgező hatás [7]. Az első generációs, alacsonyabb fütési feszültséggel múködő készülékek formaldehidkibocsátása kisebb, mint a hagyományos cigarettafüstben [19]. Ugyanakkor a második és harmadik generációs e-cigaretták múködését jellemzi, hogy a fütési feszültség növelésével a formaldehid, az acetaldehid és az aceton mennyisége 4-200-szorosára növekszik, és ez megfelel a cigarettafüstból kimutatott értékeknek [19]. Az új e-cigaretta-készülékek tehát a hagyományos cigarettával azonos vagy akár azt meghaladó mértékü rákkeltő és mérgező anyagoknak tehetik ki a használóját [19].

További sejtkárosító hatás tulajdonítható a folyadékban lévő ízesítő- és adalékanyagoknak, amelyekből hő hatására mérgező vegyületek képződhetnek [3]. Az ecigaretta-utántöltő folyadékból, illetve a képződött párából kimutatott további vegyületek (dohányspecifikus nitrózaminok [TSNA], aldehidek, fémek, illékony szerves vegyületek [VOC], policiklusos aromás szénhidrogének [PAH], dohányalkaloidok és egyéb vegyületek, például amino-tadalafil és rimonabant) nyomokban, a cigarettafüstben mérthez képest egy-három nagyságrenddel alacsonyabban fordulnak csak elő [3], azonban némelyik rákkeltő, mások sejtkárosító vagy az érelmeszesedést elősegítő kedvezőtlen hatásuk miatt figyelmet érdemelnek $[3,22]$, különös tekintettel arra, hogy a rákkeltő anyagoknak nincs küszöbdózisuk. Nikotinpótló készítményekkel való összehasonlítás során figyelmet érdemel, hogy a kibocsátott vegyületek mértéke meghaladja a nikotinos inhalátor, a nitrózaminok esetében pedig a nikotinos rágógumi használatakor mért értékeket [3,7]. Bár egyes fémek a cigarettafüsthöz képest nagyobb vagy azzal megegyező mértékben vannak jelen az e-cigarettapárában $[3,23]$, sejtkárosító, esetenként karcinogén hatásuk megfelelő gyártási technológia alkalmazásával kiküszöbölhető lenne [24].

\section{A pára egészségre gyakorolt hatásai}

Az e-cigaretta-utántöltő folyadékban lévő nikotin ultrafinom részecskék $(\mathrm{d} \approx 100-200 \mathrm{~nm})$ formájában jut a szer- vezetbe [3]. Vizsgálatok megállapították, hogy a készülékek által elóállított részecskeméret függ a folyadékban lévő nikotin mennyiségétől és megfelel a cigarettafüstben mértnek, noha a részecskeszám egyes készülékek esetében magasabb lehet [3]. Hasonló mértékû a véráramba jutó részecskék mennyisége is: míg az e-cigaretta-párában lévő részecskék 20-27\%-a, a cigarettafüst részecskéinek 25-35\%-a szívódik fel [3]. Kutatások egyértelműen alátámasztják, hogy a cigarettafüstben vagy légszennyezéskor a levegőben lévő szálló por finom és ultrafinom részecskéi hozzájárulnak a tüdőszövet és az egész szervezet gyulladásos folyamataihoz, valamint növelik a szív- és érrendszeri, légzőszervi betegségek előfordulásának és a halálozás kockázatát [3]. Mindezek tükrében valószínú, hogy az e-cigaretta hasonlóképpen részt vesz e folyamatok előidézésében. Klinikai vizsgálatokban a pára beszívását követő obstruktív hatások (légutak ellenállásának növekedése) megfeleltek a hagyományos cigaretta elszívása után tapasztaltaknak, ezért minden valószínúség szerint a hosszú távú használat során az e-cigaretta ugyanilyen elváltozásokat okozhat a tüdőfunkcióban $[3,25]$. Egyes vizsgálatok az allergiás asztma súlyosbodását írták le a pára hatására [26], más vizsgálatokban citokinek és gyulladásos mediátorok kiáramlását igazolták a tüdőszövetben $[3,27]$.

Az eddigi vizsgálatok alapján úgy tünik, hogy az e-cigaretta használata során a kilélegzett párában jelen lévő részecskék minden, zárt térben tartózkodó személy egészségére ártalmasak [28]. Az aeroszol szállópor-koncentrációja meghaladja az Egészségügyi Világszervezet (WHO) hosszú távon elfogadható iránymutató határértékét [14], a szívre és tüdőre gyakorolt káros hatásain keresztül pedig növeli a halálozás kockázatát, valamint hozzájárul a nikotinfüggőség kialakulásához [29]. Éppen ezért, a WHO az e-cigaretta nyilvános helyeken való használatát, a hagyományos cigarettához hasonlóan, korlátozni javasolja [28]. Az e-cigaretta-használó által kilélegzett párában lévő részecskék kiülepednek a zárt térben lévő felületekre, és így hosszú távon veszélyforrást jelenthetnek a nemdohányzók, különösen a kisgyermekek számára, akik a kúszás-mászás során közelebb kerülnek a szennyezett felületekhez [30]. Egyelőre nincs arra vonatkozó bizonyíték, hogy gyakoribb szellőztetéssel, ventilációval, légkondicionálással csökkenteni lehetne a kiülepedett részecskék előfordulását. A kárpitozott felületekről, szőnyegekről való eltávolításuk például különösen nehézkes lehet. A nikotin a berendezési tárgyak felszínén reakcióba léphet salétromos savval, és karcinogén nitrózaminokat képezhet. A szennyező részecskék a bőrön, a légutakon vagy az emésztőrendszeren keresztül kerülhetnek a szervezetbe. A beltéri salétromossavszennyezés leggyakoribb forrásai a nem jól szellőző gázkészülékek, de a legtöbb gépjármű belső égésű motorja is nitrogén-oxidokat bocsájt ki, ami a levegőben található vízgőzzel reagálva salétromos savvá és salétromsavvá alakul [30]. 


\section{Az e-cigaretta használatának terjedése}

Az e-cigarettát mind többen ismerik világszerte, az utóbbi években számos országban megkétszereződött azoknak a serdülóknek és felnőtteknek a száma, akik kipróbálták a terméket [3]. Az Európai Unió 15 évesnél idősebb lakosai körében 2014-ben végzett felmérés alapján az e-cigaretta kipróbálásának aránya (12\%) jelentősen emelkedett a két évvel korábban becsült értékhez (7\%) képest [31]. Aktuálisan a megkérdezettek 2\%-a használta, ezen belül a dohányzók, illetve a leszokott dohányosok kissé nagyobb arányban (4\%, illetve 3\%) [31]. Az Egyesült Államokban hasonló eredményeket mutatott egy országos felmérés. Míg 2011-ben a felnőttek mintegy 6\%-a, addig 2014-ben már 15\%-a kipróbálta és 5\% jelenleg is használja az e-cigarettát; dohányzói státusz alapján a dohányzók 21\%-a, a leszokott dohányosok 4\%-a, míg a nemdohányzók 1\%-a használ rendszeresen e-cigarettát $[3,32]$. Magyarországon is az e-cigaretta emelkedő arányú használata tapasztalható a felnőtt lakosság körében; míg 2012-ben a 18 éven felüliek 2\%-a használta, 2013-ra ez az arány több mint 4\%-ra emelkedett [33]. A nemzetközi felmérések rámutattak arra, hogy az e-cigarettát kipróbálók és használók aránya legmagasabb a fiatal felnőtt korosztályban [31, 32].

Az e-cigaretta elterjedését követő években a készüléket kizárólag dohányzók használták, az elmúlt pár évben azonban mind nagyobb számban választják a leszokott dohányosok [3], illetve a korábban nem dohányzó fiatalok $[3,34,35]$. A termék intenzív, sokszor hírességek általi reklámozása, az újdonság varázsa, a fiatalok ízlésének kedvező gyümölcsös és cukorka ízesítésü folyadékok forgalmazása, valamint a kortársak nyomásgyakorlása folytán kiskorúak körében az Egyesült Államokban három év alatt mintegy nyolcszorosára emelkedett az e-cigaretta használata (2011-ben 1,05\%, 2014-ben 8,7\%) $[3,36,37]$. Az Egyesült Államokban az e-cigarettát valaha kipróbáló 12-14 évesek, illetve 15-18 évesek 20,3\%a, illetve $7,2 \%$-a még sohasem használt hagyományos cigarettát [3]. Magyarországon a 13-15 éves korosztályba tartozó, még soha nem dohányzó fiatalok 2,9\%-a használt e-cigarettát 2012-ben, míg 2013-ra ez az arány 4\%ra emelkedett [33]. Figyelmet érdemel egy középiskolások körében végzett vizsgálat megállapítása, miszerint a csak e-cigarettát használó fiataloknál kisebb valószínúséggel mérhetô társas és magatartásbeli kockázati tényező, mint a hagyományos cigarettát használóknál [38]. $\mathrm{Az}$ eredmények felvetik annak a lehetőségét, hogy az e-cigaretta olyan fiatalok számára is vonzó lehet, akik egyébként tartózkodnának bármilyen dohánytermék használatától [38].

Fontos annak a hangsúlyozása is, hogy eltérő indíttatásból fordulnak a fiatalok és a felnőtt korosztály az e-cigaretta felé. A felnőtt dohányzókat leggyakrabban a dohányzás csökkentése és a leszokás iránti vágy buzdítja a használatra, illetve, hogy általa kiváltsák a dohányzást olyan helyeken, ahol nem lehet füstölni [3]. A fiatalok esetében az egészségnyereség reménye és a kedvtelés mellett számos egyéb tényező (családban, baráti körben való dohányzás, rosszabb iskolai teljesítés, kockázatkereső magatartás, droghasználat) is hozzájárul az e-cigaretta kipróbálásához [39-42]. A vizsgálatok szerint a fiatalok között is legnagyobb arányban a dohányzók kezdenek e-cigarettát használni. Amerikai fiatalok körében a hagyományos és az e-cigaretta együttes használata a leggyakoribb használati mód [3], ugyanakkor kiemelt figyelmet érdemel, hogy korábban nem dohányzó fiatalok is mind nagyobb arányban próbálják ki az e-cigarettát, és ezáltal akár a függőséget okozó nikotinnal is kapcsolatba kerülnek $[3,34,35]$.

$\mathrm{Az}$ e-cigaretta elterjedése fiatalok körében alááshatja azt a küzdelmet, amely az elmúlt évtizedekben a dohányzás társadalmi elutasításáért [43] és a fiatalok dohányzása ellen folyt [37]. Növekvő számú vizsgálat bizonyítja, hogy a fiatalon elkezdett e-cigaretta-használat hajlamosít a különböző dohánytermékek használatára kora serdülókorban [42], és a kialakult függőség fogékonnyá tesz a további droghasználat iránt $[44,45]$.

\section{A e-cigaretta leszokásban játszott szerepe nem bizonyított}

Az e-cigaretta nem tekinthetô leszokást támogató eszköznek, mégis számos, e-cigarettát támogató társaság és forgalmazó a dohányzásról való leszokást segító készülékként reklámozza [3]. A témában végzett vizsgálatok rámutatnak, hogy a felnőtt e-cigaretta-használók többsége a dohányzásról való leszokás reményében próbálja ki a készüléket [3]. Továbbra sincs azonban tudományos bizonyíték arra, hogy az e-cigaretta alkalmas volna a dohányzás okozta fizikai, pszichés és motivációs függőség kezelésére [46]. Az e-cigarettának a leszokás támogatásában játszott pozitív szerepét hangoztató első vizsgálatokban komoly módszertani és etikai hibák találhatók [3], viszont az újabb, módszertanilag helytálló vizsgálatok alapján kijelenthetó, hogy az e-cigarettának a leszokást támogató hatékonysága nem haladja meg a többi nikotinpótló készítményét [46]. Egyes vizsgálatok éppen arra világítottak rá, hogy az e-cigaretta-használók kevésbé szoknak le, mint azok, akik nem használnak ecigarettát, habár ez összefüggésben lehet azzal, hogy az erôs nikotinfüggőségben szenvedők nagyobb arányban próbálják ki az e-cigarettát a leszokás reményében [3]. $\mathrm{Az}$ e-cigaretta a nikotintartalom mértékétől függően csökkenti a megvonási tüneteket, jóllehet, a korábbi dohányosok esetében hatékonyabban, mint a jelenleg dohányzóknál. Hatékonysága megfelel a nikotinos inhalátor használatakor tapasztaltnak, ugyanakkor kényelmi szempontok miatt az e-cigaretta inkább közkedvelt a leszokni kívánók körében $[3,14]$. A leszokásra motivált személyeknél, a készülék típusától és a nikotintartalomtól függően, az e-cigaretta használata valószínúleg csökkentheti az elszívott cigaretták számát, ezzel együtt a nikotin tartós és nem csökkenő dózisú bevitele fenntart- 
ja a nikotinfüggőséget $[42,46]$. A felsoroltak okán magas azon személyek aránya, akik a leszokás szándékával kezdik el használni az e-cigarettát, de áttérnek annak hosszú távú használatára [3], vagy kialakul náluk a kettős használat gyakorlata: zárt térben az e-cigarettát, szabad téren a hagyományos cigarettát fogyasztják [3]. Hangsúlyozni szükséges, hogy az utóbbi esetekben az ártalom nem csökken, sőt az e-cigaretta használata károsan befolyásolhatja a végleges leszokás folyamatát [3].

\section{Mit tanácsoljon a klinikus a páciensnek?}

Ha egy páciens megkérdezi orvosa véleményét az e-cigaretta leszokásban betöltött szerepéről, az a leszokási szándékát jelezheti. Érdemes kihasználni ezt a lehetőséget és megerősíteni a páciens pozitív attitűdjét a leszokáshoz. Dohányzási szokásainak, esetleges korábbi leszokási kudarcainak megismerése után célszerü a páciensnek a dohányzásról való leszokást támogató valamelyik programot javasolni (telefonos, egyéni, illetve csoportfoglalkozás). Ha az illető már használ e-cigarettát, fontos felhívni a figyelmét a hagyományos cigaretta teljes elhagyásának szükségességére, hiszen a kettős használat következtében fokozottan nő az egészségkárosodás valószínűsége. Az e-cigaretta-használóban tudatosítani kell, hogy az egységes szabályokat és gyakran minőségkontrollt nélkülöző gyártási folyamat miatt különösen fennáll annak a veszélye, hogy egészségkárosító anyagoknak van kitéve a használó, ugyanakkor nincs bizonyítva, hogy az e-cigaretta hatékony lenne a leszokás támogatásában. Hangsúlyozni szükséges továbbá, hogy kerülje az e-cigaretta használatát zárt térben, illetve gyermekek közelében annak érdekében, hogy ezáltal csökkentse az eszköz párájával kilélegzett nikotin és más potenciálisan mérgező anyagok passzív expozíciójának kockázatát. Mivel már részben ismerjük az egyes összetevők hosszú távú egészségkárosító hatását, javasoljuk az e-cigarettáról való leszokás dátumát is kijelölni [3].

\section{Az e-cigaretta terjedésének népegészségügyi szempontjai}

Az e-cigaretta feltételezett ártalomcsökkentő szerepével szemben állnak azok a jelenségek, amelyek egyéni és társadalmi szinten is növelik a dohányzás betegségterhét. Ilyen lehet, ha a végleges leszokás helyett az e-cigaretta hosszú távú használatát választja a dohányzó, továbbá, ha a dohányzás mellett e-cigarettát is használ, valamint, ha korábban leszokott dohányzó kezdi el használni a terméket, illetve, ha korábban nem dohányzó kísérletezik az e-cigaretta-használattal. A megfigyelt jelenségek nagy részét a dohánygyárak érdekeit kifejező piaci viszonyok alakítják, éppen ezért különösen fontos figyelemmel kísérni, hogy az e-cigaretta és más dohánytermékek együttes használata hosszú távon a füstképző dohánytermékek elhagyását vagy ezek folyamatos használatát eredménye- zik-e. Ugyancsak figyelmet érdemel az a jelenség, hogy az e-cigaretta-használók mintegy harmada már nem dohányzik a készülék használatának kezdetekor, mi több, minden tizedik korábbi dohányos esetében több mint öt év telt el a leszokásuk óta [47]. További vizsgálatok szükségesek annak felderítésére, hogy az e-cigaretta használatát azért választják-e a leszokott dohányosok, hogy megelőzzék a visszaesést, vagy az ismételt nikotinbevitel okán visszaszoknak a dohányzásra [47]. Aggodalomra ad okot, hogy az e-cigaretta és a füstképző dohánytermékek együttes használata kiemelten magas arányt mutat az alacsony iskolai végzettségú, alacsony jövedelmû és rossz egészségi állapottal bíró populációban, ezért a fenti termékek változatlan mértékü használata jelentős népegészségügyi veszélyforrást jelenthet [32]. A termék ártalomcsökkentő szerepét hangsúlyozó intenzív reklámozás miatt a várandósok körében is egyre elterjedtebb az a nézet, hogy az e-cigaretta használata biztonságos alternatívája lehet a dohányzásnak [48]. Tekintettel a nikotin által a magzatra és a terhességre gyakorolt ismert káros hatásokra, különösen nyugtalanító, hogy megfelelő prevenciós tevékenység (felvilágosítás a káros hatásokról, leszokástámogatási lehetőségekről) hiányában növekvő arányban választhatják dohányzó várandós nók is az e-cigarettát [49].

A dohányzás visszaszorítására és a leszokás támogatására hozott intézkedések hatékonysága érdekében kívánatos, hogy az e-cigarettára ugyanazok a szabályok vonatkozzanak, mint a hagyományos dohánytermékekre, azaz a dohányzást tiltó helyeken ne lehessen e-cigarettát sem használni, tilos legyen a termék reklámozása, illetve az ízesító aromák használata [3]. Az amerikai szövetségi államok több mint fele korlátozza az e-cigaretta használatát, és ennek érdekében a következő szabályozásokat vezette be: életkorhoz kötötte a dohánytermékekhez, így az amerikai szabályozás szerint annak minősülő e-cigarettához való hozzáférést, a füstmentes levegőt előíró törvények korlátozzák, hogy hol lehet „rágyújtani”, illetve jövedéki adót vetnek ki a különböző dohánytermékekre, így az e-cigarettára is [50]. Beláthatatlan károkat okozna, ha a cigarettához hasonlóan, az e-cigaretta azelőtt válna népszerûvé és társadalmilag elfogadottá, mielőtt a lakosság megismerhetné annak egészségkárosító hatásait.

Anyagi támogatás: A közlemény megírása, illetve a kapcsolódó forrásmunka anyagi támogatásban nem részesült.

Szerzői munkamegosztás: Cs. Zs.: Forrásmunka, a kézirat megszövegezése. P. M.: A kézirat korrektúrázása, kiegészítő forráskutatás. A cikk végleges változatát mindkét szerző elolvasta és jóváhagyta.

Érdekeltségek: A szerzőknek nincsenek érdekeltségeik. 


\section{Irodalom}

[1] U.S. Department of Health and Human Services: How tobacco smoke causes disease: the biology and behavioral basis for smoking-attributable disease: A report of the Surgeon General. U.S Department of Health and Human Services, Centers for Disease Control and Prevention, National Center for Chronic Disease Prevention and Health Promotion, Office on Smoking and Health, Atlanta, GA, 2010. http://www.ncbi.nlm.nih.gov/ books/NBK53017/

[2] Proctor, R. N.: Golden holocaust: origins of the cigarette catastrophe and the case for abolition. University of California Press, Berkeley and Los Angeles, 2011.

[3] Grana, R., Benowitz, N., Glantz, S. A.: E-cigarettes. A scientific review. Circulation, 2014, 129(19), 1972-1986.

[4] Callahan-Lyon, P.: Electronic cigarettes: human health effects. Tob. Control., 2014, 23(Suppl. 2), ii36- ii40.

[5] Cselkó, Z., Kovács, G.: The known and unknown facts about electronic cigarettes. [Az elektromos cigarettáról: amit tudni lehet és amit nem.] Medicina Thoracalis, 2013, 66(4), 166-177. [Hungarian]

[6] National Center for Chronic Disease Prevention and Health Promotion (US) Office on Smoking and Health: The health consequences of smoking -50 years of progress. A report of the Surgeon General. Centers for Disease Control and Prevention (US), Atlanta (GA), 2014. http://www.surgeongeneral.gov/library/ reports/50-years-of-progress/full-report.pdf

[7] Visser, W., Geraets, L., Klerx, W., et al.: The health risks of using e-cigarettes. RIVM Letter Report, 2015-0144. http://www. rivm.nl/dsresource?objectid=rivmp:28431 1 \&type $=$ org\&disposi tion=inline\&ns_nc=1

[8] Norwegian Institute of Public Health: Health risks associated with e-cigarette use - English summary. 2015. http://www.fhi. no/dokumenter/136f74lble.pdf

[9] Etter, J. F.: Levels of saliva cotinine in electronic cigarette users. Addiction, 2014, 109(5), 825-829.

[10] Marsot, A., Simon, N.: Nicotine and cotinine levels with electronic cigarette: A review. Int. J. Toxicol., 2016, 35(2), 179185 .

[11] Chatham-Stephens, K., Law, R., Taylor, E., et al.: Notes from the field: Calls to poison centers for exposures to electronic cigarettes - United States, September 2010-February 2014. MMWR Morb. Mortal. Wkly Rep., 2014, 63(13), 292-293.

[12] Christensen, L. B., van't Veen, T., Bang, J.: Three cases of attempted suicide by ingestion of nicotine liquid used in e-cigarettes. Paper presented at: XXXIII International Congress of the European Association of Poisons Centres and Clinical Toxicologists (EAPCCT), 28-31 May 2013, Copenhagen, Denmark. Clin. Toxicol., 2013, 51, 290, Abstract 85

[13] Chen, B. C., Bright, S. B., Trivedi, A. R., et al.: Death following intentional ingestion of e-liquid. Clin. Toxicol. (Phila.), 2015, $53(9), 914-916$.

[14] German Cancer Research Center (ed.): Electronic cigarettes - An overview. Heidelberg, 2013. https://www.dkfz.de/en/presse/ download/RS-Vol19-E-Cigarettes-EN.pdf

[15] Mayer, B.: How much nicotine kills a human? Tracing back the generally accepted lethal dose to dubious self-experiments in the nineteenth century. Arch. Toxicol., 2014, 88(1), 5-7.

[16] Directive 2014/40/EU of the European Parliament and of the Council on the approximation of the laws, regulations and administrative provisions of the Member States concerning the manufacture, presentation and sale of tobacco and related products and repealing Directive 2001/37/EC. [Az Európai Parlament és a Tanács 2014/40/EU irányelve a tagállamoknak a dohánytermékek és kapcsolódó termékek gyártására, kiszerelésére és értékesítésére vonatkozó törvényi, rendeleti és közigazgatási rendelkezései közelítésérôl és a 2001/37/EK irányelv hatá- lyon kívül helyezéséről]. http://ec.europa.eu/health/tobacco/ docs/dir_201440_hu.pdf [Hungarian]

[17] Drugs-Forum: Dissolving heroin in e-cigarette liquid then smoking it in a e-cig? https://drugs-forum.com/forum/showthread. php?t=173636

[18] Mackey, T. K., Miner, A., Cuomo, R. E.: Exploring the e-cigarette e-commerce marketplace: Identifying internet e-cigarette marketing characteristics and regulatory gaps. Drug Alcohol. Depend., 2015, 156, 97-103.

[19] Kosmider, L., Sobczak, A., Fik, M., et al.: Carbonyl compounds in electronic cigarette vapors - effects of nicotine solvent and battery output voltage. Nicotine Tob. Res., 2014, 16(10), 13191326.

[20] Kienhuis, A. S., Soeteman-Hernandez, L. G., Bos, P. M., et al.: Potential harmful health effects of inhaling nicotine-free shishapen vapor: a chemical risk assessment of the main components propylene glycol and glycerol. Tob. Induc. Dis., 2015, 13(1), 15.

[21] Wieslander, G., Norbäck, D., Lindgren, T.: Experimental exposure to propylene glycol mist in aviation emergency training: Acute ocular and respiratory effects. Occup. Environ. Med., 2001, 58(10), 649-655.

[22] Chang, $H .:$ Research gaps related to the environmental impacts of electronic cigarettes. Tob. Control, 2014, 23(Suppl. 2), ii54ii58.

[23] Saffari, A., Daher, N., Ruprecht, A., et al.: Particulate metals and organic compounds from electronic and tobacco containing cigarettes: comparison of emission rates and secondhand exposure. Environ. Sci. Process Impacts, 2014, 16(10), 2259-2267.

[24] Williams, M., To, A., Bozhilov, K., et al.: Strategies to reduce tin and other metals in electronic cigarette aerosol. PLoS ONE, $2015,10(9), \mathrm{e} 0138933$.

[25] Marini, S., Buonanno, G., Stabile, L., et al.: Short-term effects of electronic and tobacco cigarettes on exhaled nitric oxide. Toxicol. Appl. Pharmacol., 2014, 278(1), 9-15.

[26] Lim, H. B., Kim, S. H.: Inhallation of e-cigarette cartridge solution aggravates allergen-induced airway inflammation and hyperresponsiveness in mice. Toxicol. Res., 2014, 30(1), 13-18.

[27] Cervellati, F., Muresan, X. M., Sticozzi, C., et al.: Comparative effects between electronic and cigarette smoke in human keratinocytes and epithelial lung cells. Toxicol. in Vitro, 2014, 28(5), 999-1005.

[28] WHO: World Health Organization Framework Convention on Tobacco Control. http://apps.who.int/gb/fctc/PDF/cop6/ FCTC_COP6_10-en.pdf?ua $=1$

[29] Ruprecht, A. A., De Marco, C., Pozzi, P., et al.: Comparison between particulate matter and ultrafine particle emission by electronic and normal cigarettes in real-life conditions. Tumori, 2014, 100(1), e24-e27.

[30] Kuschner, W. G., Reddy, S., Mehrotra, N., et al.: Electronic cigarettes and thirdhand tobacco smoke: two emerging health care challenges for the primary care provider. Int. J. Gen. Med., 2011, 4, 115-120.

[31] European Commission: Special Eurobarometer 429 "Attitudes of Europeans towards Tobacco and Electronic Cigarettes". European Union, 2015. http://ec.europa.eu/COMMFrontOffice/ PublicOpinion/index.cfm/Survey/getSurveyDetail/instruments/SPECIAL/surveyKy/2033

[32] Weaver, S. R., Majeed, B. A., Pechacek, T. F., et al.: Use of electronic nicotine delivery systems and other tobacco products among USA adults, 2014: results from a national survey. Int. J. Public Health, 2016, 61(2), 177-188.

[33] National Institute for Health Development, Hungarian Focal Point for Tobacco Control: The use of electronic cigarettes and electronic devices imitating smoking, 2015. [Nemzeti Egészségfejlesztési Intézet, Dohányzás Fókuszpont: Az elektronikus cigaretták és a dohányzást imitáló elektronikus eszközök használatának gyakorisága, 2015.] http://www.fokuszpont.dohanyzasvissza- 
szoritasa.hu/sites/default/files/e_cigaretta_gyakorisag.pdf [Hungarian]

[34] Czoli, C. D., Hammond, D., White, C. M.: Electronic cigarettes in Canada: prevalence of use and perceptions among youth and young adults. Can. J. Public Health, 2014, 105(2), e97-e102.

[35] Dautzenberg, B., Berlin, I., Tanguy, M. L., et al.: Factors associated with experimentation of electronic cigarettes among Parisian teenagers in 2013. Tob. Induc. Dis., 2015, 13(1), 40.

[36] Camenga, D. R., Delmerico, J., Kong, G., et al.: Trends in use of electronic nicotine delivery systems by adolescents. Addict. Behav., 2014, 39(1), 338-340.

[37] Arrazola, R. A., Singh, T., Corey, C. G., et al.: Tobacco use among middle and high school students - United States, 20112014. MMWR Morb. Mortal. Wkly Rep., 2015, 64(14), 381385.

[38] Wills, T. A., Knight, R., Williams, R. J., et al.: Risk factors for exclusive e-cigarette use and dual e-cigarette use and tobacco use in adolescents. Pediatrics, 2015, 135(1), e43-e51.

[39] Nădăşan, V., Foley, K. L., Pénzes, M., et al.: Use of electronic cigarettes and alternative tobacco products among Romanian adolescents. Int. J. Public Health, 2016, 61(2), 199-207.

[40] Barrington-Trimis, J. L., Berbane, K., Unger, J. B., et al.: Psychosocial factors associated with adolescent electronic cigarette and cigarette use. Pediatrics, 2015, 136(2), 308-317.

[41] Saddleson, M. L., Kozlowski, L. T., Giovino, G. A., et al.: Enjoyment and other reasons for electronic cigarette use: Results from college students in New York. Addict. Behav., 2015, 54, 33-39.

[42] Leventhal, A. M., Strong, D. R., Kirkpatrick, M. G., et al.: Association of electronic cigarette use with initiation of combustible tobacco product smoking in early adolescence. JAMA, 2015, 314(7), 700-707.
[43] Choi, K., Fabian, L., Mottey, N., et al.: Young adults' favorable perceptions of snus, dissolvable tobacco products, and electronic cigarettes: findings from a focus group study. Am. J. Public Health, 2012, 102(11), 2088-2093.

[44] Kandel, E. R., Kandel, D. B.: Molecular basis for nicotine as a gateway drug. N. Engl. J. Med., 2014, 371(10), 932-943.

[45] Kristjansson, A. L., Mann, M. J., Sigfusdottir, I. D.: Licit and illicit substance use by adolescent e-cigarette users compared with conventional cigarette smokers, dual users, and nonusers. J. Adolesc. Health, 2015, 57(5), 562-564.

[46] McRobbie, H., Bullen, C., Hartmann-Boyce, J., et al.: Electronic cigarettes for smoking cessation and reduction. Cochrane Database Syst. Rev., 2014, (12), CD010216.

[47] McMillen, R. C., Gottlieb, M. A., Shaefer, R. M., et al.: Trends in electronic cigarette use among U.S. adults: use is increasing in both smokers and nonsmokers. Nicotine Tob. Res., 2015, 17(10), 1195-1202.

[48] Kahr, M. K., Padgett, S., Shope, C. D., et al.: A qualitative assessment of the perceived risks of electronic cigarette and hookah use in pregnancy. BMC Public Health, 2015, 15(1), 1273.

[49] Baeza-Loya, S., Viswanath, H., Carter, A., et al.: Perceptions about e-cigarette safety may lead to e-smoking during pregnancy. Bull. Menninger Clin., 2014, 78(3), 243-252.

[50] Gourdet, C. K., Chriqui, J. F., Chaloupka, F. J.: A baseline understanding of state laws governing e-cigarettes. Tob. Control, 2014, 23(Suppl. 3), iii37-iii40.

(Cselkó Zsuzsa dr., e-mail: cselkozsuzsa@hotmail.com)

\section{A Magyar Személyre Szabott Medicina Társaság VII. kongresszusa}

\section{A személyre szabott orvoslás hatása a jövő egészségügyére}

A Magyar Személyre Szabott Medicina Társaság életre hivásával az egészségipar, kutatás-fejlesztés és orvoslás terén müködő szereplők kötelezettséget vállaltak arra, hogy munkájukkal hozzájáruljanak ahhoz, hogy a hazai egészségügy és annak müködési elvei terén az elkövetkezendő években jelentős változások mehessenek végbe. A Személyre Szabott Orvoslás (SZSZO) paradigmaváltást jelent a gyógyításban, egészség-gazdaságban, transzlációs medicinában. Ennek szellemében kerül sor hetedik kongresszusunkra, melynek elöadásai $A$ személyre szabott orvoslás hatása a jövő egészségügyére témára összpontosulnak.

\section{A konferencia időpontja: 2016. augusztus 26-27. \\ A konferencia helyszíne: Abacus Hotel, Herceghalom}

A konferencia pontszerző tanfolyamnak minősül, mind a szakorvosok, mind a PhD hallgatók számára: OFTEX pontértéke: 32

GYOFTEX pontértéke: 32

A kongresszussal kapcsolatos egyéb információk, program, jelentkezési lap és részvételi dij az MSzMT honlapján (www.mszmt.hu) olvashatók.

Regisztrációs határidő: $\quad$ 2016. július 31 .

Kontakt: $\quad$ Polyák Krisztina $\quad$ - telefon: (06-20) 403-4955

Zeitlerné Kozma Zsuzsanna - telefon: (06-20) 414-9646

Szeretettel várjuk jelentkezését!

Dr. Németh György elnök 